\title{
How to successfully publish interdisciplinary research: learning from an Ecology and Society Special Feature
}

\author{
Christian Pohl ${ }^{1,2}$, Gabriela Wuelser $^{2}{ }^{2}$ Peter Bebi ${ }^{3}$, Harald Bugmann ${ }^{4}$, Alexandre Buttler ${ }^{5,6,7}$, Ché Elkin ${ }^{4,8}$, Adrienne Grêt-Regamey $^{9}$, \\ Christian Hirschi $^{10}$, Quang Bao Le ${ }^{11,12}$, Alexander Peringer ${ }^{5,6}$, Andreas Rigling $^{6}$, Roman Seidl $^{11}$ and Robert Huber $^{6}$
}

\begin{abstract}
What are the factors that hinder or support publishing interdisciplinary research? What does a successful interdisciplinary publishing process look like? We address these questions by analyzing the publishing process of the interdisciplinary research project titled "Mountland." Project researchers published most of their main results as a Special Feature of Ecology and Society. Using the story wall method and qualitative content analysis, we identified ten factors contributing to the success or failure of publishing interdisciplinary research. They can be assigned to four groups of resources: scientific resources, i.e., previous joint research, simultaneously written manuscripts; human resources, i.e., coordination, flexibility, composition of the team; integrative resources, i.e., vision of integration, chronology of results; and feedback resources, i.e., internal reviews, subject editors, external reviewers. According to this analysis, an ideal-typical publishing process necessitates, among other things, (1) a strong, interdisciplinary coordinator, (2) a clear shared vision of integration and a common framework, (3) flexibility in terms of money and time, (4) a certain sense of timing regarding when and how to exchange results and knowledge, (5) subject editors who are familiar with the specific project and its interdisciplinary merits, and (6) reviewers who are open minded about interdisciplinary efforts.
\end{abstract}

Key Words: hindering and supporting factors; interdisciplinary publishing; Mountland

\section{INTRODUCTION}

Often scholars complain about how difficult it is to publish interdisciplinary research. The reasons they give include problems with finding an adequate journal, reviewers who do not value interdisciplinary contributions, or more basic concerns as expressed by a social scientist: "As a sociologist to collaborate intimately with a biologist. What should we write about? I don't know!" (Pohl 2005:1169). In this context, at least four trends in the scientific system need to be taken into account when asking how to successfully publish interdisciplinary research.

First, over the past years, publishing in teams has been observed to be a general trend within academia (Hicks and Katz 1996). In natural, engineering, and social sciences, the number of authors per article in Web of Science publications has steadily increased over the last 50 years. Only in arts and humanities do $90 \%$ of the publications remain single-author monographs (Wuchty et al. 2007, Jones et al. 2008). Because the number of authors of a paper seems to positively correlate with how often it is quoted (Gazni und Didegah 2011), publishing in teams appears to be the proper strategy in times when scientific achievements are primarily measured quantitatively, by the $h$-index among other factors. Hence, publishing in teams is not a specific phenomenon of social-ecological research or of research for sustainable development, but a general phenomenon.

Second, publishing in teams mirrors the more generic trend of doing research in collaboration. According to Bozeman et al.
(2013:1), "there is abundant evidence that research collaboration has become the norm in every field of scientific and technical research." A key indicator that has been used "as a basic counting unit to measure collaborative activity" is coauthorship, again mostly because it is easy to quantify (Katz and Martin 1997:2). However, because research collaboration encompasses much more than collectively writing a paper, this does not answer satisfactorily the question of how to adequately express collaborative research contributions in terms of authorship. Cheruvelil et al. (2014) have suggested that researchers should agree on an authorship/coauthorship policy to clarify this question early in a project. Furthermore, a group of journal editors and universities have recently proposed and tested a contributor role taxonomy to make each researcher's specific contribution to a paper transparent (Allen et al. 2014). Of the 14 suggested taxonomy criteria, 3 address paper writing: writing the initial draft; critical review, commentary, or revision; and visualization/data presentation. The remaining 11 categories include, but are not limited to, contributions to study conception, supervision, or funding acquisition. However, key contributions like a "brilliant suggestion made by a scientist during casual conversation" (Katz and Martin 1997:2) are still beyond the scope of that taxonomy. Thus, analyzing successful interdisciplinary publishing means to focus on one specific element within the complex and comprehensive process of research collaboration, the element that counts most for scientific merit.

\footnotetext{
${ }^{1}$ Transdisciplinarity Lab USYS TdLab, Department of Environmental Systems Science, ETH Zurich, ${ }^{2}$ Network for Transdisciplinary Research tdnet, Swiss Academies of Arts and Sciences, ${ }^{3}$ WSL-Institute for Snow and Avalanche Research SLF, ${ }^{4}$ Forest Ecology, Department of Environmental Systems Science, ETH Zurich, ${ }^{5}$ Ecole Polytechnique Fédérale de Lausanne EPFL, School of Architecture, Civil and Environmental Engineering ENAC, Laboratory of Ecological Systems ECOS, ${ }^{6}$ Swiss Federal Institute for Forest, Snow and Landscape Research WSL, ${ }^{7}$ Laboratoire de Chrono-Environnement, UMR CNRS 6249, UFR des Sciences et Techniques, ${ }^{8}$ Ecosystem Science and Management, University of Northern British Columbia, ${ }^{9}$ Planning of Landscape and Urban Systems, Department of Civil, Environmental and Geomatic Engineering, ETH Zurich, ${ }^{10}$ Environmental Policy and Economics, Department of Environmental Systems Science, ETH Zurich, ${ }^{11}$ Department of Environmental Systems Science, ETH Zurich, ${ }^{12}$ CGIAR Program in Dryland Systems
} 
Third, collaboration in teams does not necessarily have to be interdisciplinary. We refer to interdisciplinarity as to "a mode of research by teams or individuals that integrates information, data, techniques, tools, perspectives, concepts, and/or theories from two or more disciplines or bodies of specialized knowledge to advance fundamental understanding or to solve problems whose solutions are beyond the scope of a single discipline or area of research practice" (NAS/NAE/IOM 2005:2). This broad understanding covers a plurality of specific definitions, for which Klein (2010) provided a detailed taxonomy. According to this broad definition, the motivation for interdisciplinary research lies in the purpose of joint knowledge production, i.e., advancing fundamental understanding or solving problems. Research collaborations can, however, also be motivated by the desire of researchers "to increase their scientific popularity ..., visibility and recognition," "the need to gain experience or to train apprentice researchers in the most effective way possible" (Katz and Martin 1997:4), or by a funder trying to increase international collaboration. Hence, interdisciplinary research is a specific form of collaborative research that is motivated by the subject matter.

Fourth, the interest in better understanding and practicing collaborative research in general, and inter- and transdisciplinary research in particular, is growing. Scholars of the novel field of the science of team science (Stokols et al. 2008a, Falk-Krzesinski et al. 2011) provide, for instance, an extensive review of the intrapersonal, interpersonal, organizational/institutional, physical/ environmental, technological, and socio-political factors that influence teams and provide the context for the "ecology of team science" (Stokols et al. 2008b). Handbooks of interdisciplinarity (Frodeman et al. 2010) and of transdisciplinary research (Hirsch Hadorn et al. 2008) give an overview of the state of the art of these research forms and identify stumbling blocks (Wiesmann et al. 2008). Other publications provide methods and tools to improve the practice of collaborative, interdisciplinary, and transdisciplinary research. Among those are suggestions to facilitate interdisciplinary research (NAS/NAE/IOM 2005), the team science toolkit (Vogel et al. 2013), dialog methods for research integration (McDonald et al. 2009), methods for transdisciplinary research (Bergmann et al. 2012), tools to support teams in collaboration (Bennett et al. 2010, Cheruvelil et al. 2014), and tools to enhance interdisciplinary understanding and communication (Heemskerk et al. 2003, Winowiecki et al. 2011, O’Rourke and Crowley 2013).

We focus on the process of writing interdisciplinary articles for a Special Feature in Ecology and Society. We reduced the complexity inherent in analyzing collaborative research as follows: (1) We excluded from our analysis questions that are not primarily related to the process of collaborative interdisciplinary writing. Such questions are, for instance, whether a team is adequately managed over the whole research process, or what the scientific impact of coauthored papers is (Cheruvelil et al. 2014). (2) We did not discuss the issue of whether the chosen coauthorship model appropriately covers each researcher's contribution, because in the consortium there was a shared understanding of how to stick to the respective institutional rules. (3) We concentrated on a team's disciplinary diversity, and not, for instance, on a team's diversity in terms of race, gender, or age (Bozeman et al. 2013). (4) We focused on providing practical knowledge on how to improve interdisciplinary publishing, and not, for instance, on providing evidence of how a team's disciplinary heterogeneity relates to its publishing patterns (Porac et al. 2004, Stvilia et al. 2011, Hall et al. 2012, Cheruvelil et al. 2014). Given this focus, there were only a few studies that provide specific advice on how to improve the practice of interdisciplinary publishing. We identified six recommendations from the literature, as follows:

1. Journal editors should actively encourage publication of interdisciplinary research results, e.g., through special issues or by editorial board members with interdisciplinary experience (NAS/NAE/IOM 2005).

2. Elements such as deadlines or time constraints should be used to focus the group (Gooch 2005).

3. A basic understanding of other disciplines is required for collaborative writing (Gooch 2005).

4. The stages of paper writing, i.e., outline, drafting of parts, and revision, should be flexible enough to be accomplished in a variety of ways: by the team, by several team members, or by an individual (Ede and Lunsford 1990, Gooch 2005).

5. Publications should include both disciplinary as well as interdisciplinary insights gained on the subject (Kueffer et al. 2007)

6. Publications should include methodological insights gained on the interdisciplinary research process in the respective journals (Kueffer et al. 2007).

The goal of our analysis was to develop a broader picture of the factors that hinder or help interdisciplinary publishing, and to come up with a comprehensive set of recommendations. To this end, we evaluated the collaborative process within the interdisciplinary research project "Mountland" for publishing an Ecology and Society Special Feature. This collective process went beyond publishing the results of already-completed interdisciplinary studies. Rather, joint publishing was itself part of interdisciplinary research, such that "[i]nformation, data, techniques, tools, perspectives, concepts, and/or theories from two or more disciplines" (NAS/NAE/IOM 2005:2) continued to be further integrated when developing and writing the papers.

The ex post analysis of the interdisciplinary publishing process in Ecology and Society was guided by two research questions: (1) What are the factors that hinder or support publishing interdisciplinary research? (2) What does a successful interdisciplinary publishing process look like?

\section{THE MOUNTLAND PROJECT}

The goal of Mountland was to propose policy solutions in three case study regions of the Swiss Alps based on an analysis of the sensitivity of the provisioning of mountain ecosystem goods and services to changes in climate and land use. An integrative approach was applied, combining methods from economic, political, and natural sciences to analyze ecosystem functioning from a holistic human-environment system perspective (Huber et al. $2013 a, 2013 b$ ).

The project comprised 10 research groups and involved more than 37 researchers and PhD students (see Appendix 1). A 
management board consisting of two professors and three senior scientists strategically led the project. The research was based on seven mostly disciplinary $\mathrm{PhD}$ studies and four mostly interdisciplinary postdoctoral studies. An additional postdoctoral researcher coordinated the interdisciplinary efforts between research groups and clusters, as well as the interaction with stakeholders outside the scientific community. The analysis was organized around three clusters: an ecological, a socioeconomic, and a policy assessment task. Within each research cluster, several methods were applied, ranging from the analysis of longterm monitoring data (Barbeito et al. 2012, Rigling et al. 2013) and quantitative ecological experiments (Dawes et al. 2011, Eilmann et al. 2013, Gavazov et al. 2014) to simulation models (e.g., Elkin et al. 2012, Peringer et al. 2013, Zurbriggen et al. 2014) and social network analysis (Hirschi et al. 2013). The integration across research clusters relied strongly on a modeling approach: the Alpine Land Use Allocation Model allowed us to combine ecological conditions and socioeconomic developments into an integrated framework (Briner et al. 2012). This framework served as a tool to relate climate-induced and economically driven changes (Briner et al. 2013a) to trade-off analysis (Briner et al. 2013b), as well as to policy assessments (Hirschi et al. 2013, Huber et al. 2013c).

The interdisciplinary nature of Mountland was promoted from the outset of the project because it was partly funded by the Competence Center Environment and Sustainability of the ETH Domain (CCES). The goal of CCES was to support inter- and transdisciplinary research to facilitate the integration of sustainable development principles into country policies and programs (Kueffer et al. 2012). Within the frame of CCES, interdisciplinarity stands for the collaboration across disciplines, whereas transdisciplinarity goes beyond interdisciplinarity by also including the engagement with societal stakeholders. This is one common understanding of interdisciplinarity and transdisciplinarity (Hirsch Hadorn et al. 2008, Klein 2010). Another common understanding is that transdisciplinarity goes beyond interdisciplinarity by a higher degree of integration of disciplinary insights or by a higher diversity of the disciplines involved (Rosenfield 1992, Stokols et al. 2003). Throughout this paper, we adhere to the former definition.

As part of CCES, Mountland had access to specific funding that explicitly supported interdisciplinary efforts of postdoctoral candidates. To add value to the inter- and transdisciplinary efforts in Mountland, results were published not only in Ecology and Society but also in two Special Issues of journals at the interface between science and stakeholders from the Swiss agricultural and forestry sectors, respectively, that are not indexed by the Institute for Scientific Information (Huber et al. $2012 a, 2012 b)$.

To prepare the Special Feature of Ecology and Society, the researchers of Mountland carved the niches for a set of interdisciplinary article contributions in a one-day workshop in May 2011. This effort included the discussion of first-authorship and coauthorship based on research work and the involvement in the writing of the paper. Because the inter- and transdisciplinary contributions had to be submitted within a given time frame, i.e., by February 2012, intensive coordination between research groups was required and the writing processes needed to be synchronized. The interdisciplinary articles were subjected to a proper submission and external review process. Three subject editors from within the project guided this process by suggesting independent and qualified reviewers, and coordinating the communication between authors, reviewers, and the editor-in-chief. In 2013, the ten articles were successively published online (http://www.ecologyandsociety.org/issues/view. php?sf=75; see Table 1).

\section{METHOD}

\section{Data collection using the story wall method}

For identifying the crucial factors that had supported and hindered the process of jointly developing and writing the papers, we used an integration method called the story wall (Smit 2005). This method makes use of the fact that interdisciplinary publishing processes can be perceived and reproduced as stories. It allows considering that the members of a group may at least partly experience a process in different ways and stress different elements as having been important. Through storytelling, the individual perspectives can be collected and a joint understanding of the past can be created.

In our case, the stories concerned publishing interdisciplinary research both on the level of the single papers (papers 1-9) and on level of the overall synthesis (paper 10). We discussed this process with its subprocesses in a workshop that brought together all coauthors. Two scientists who are experienced in analyzing disciplinary, interdisciplinary, and transdisciplinary research facilitated the workshop, which was structured in six steps:

1. As a starting point, a simple timeline indicating the start and the end dates of the joint interdisciplinary publishing process was provided for each group of authors of the Ecology and Society Special Feature papers.

2. The authors of each paper collectively discussed whether to further structure the paper's timeline, e.g., into the main publication process phases.

3. The authors individually identified key events or dominant influences, influences or events that supported the publication process, and influences or events that hindered it.

4. Based on the individual story walls, the authors jointly created a story wall picture for each paper, representing the author group's collective understanding of the process.

5. Each paper's story wall was briefly presented and discussed in a plenary session.

6. Out of the factors that were stressed repeatedly, an idealtypical story wall picture was drafted.

\section{Data analysis}

After the workshop, the coordinator of Mountland and the two scholars experienced in analyzing disciplinary, interdisciplinary, and transdisciplinary research formed a subteam for analyzing the story walls. Data analysis was based on the qualitative methodology of grounded theory (Glaser and Strauss 1967). Applying a qualitative approach enabled us to account for the 
Table 1. Overview of the"Mountland" Special Feature in Ecology and Society (http://www.ecologyandsociety.org/issues/view.php? $\underline{\mathrm{sf}=75}$ ).

\begin{tabular}{|c|c|c|c|c|c|}
\hline \multicolumn{2}{|c|}{ No. Title and source } & \multirow{2}{*}{$\frac{\text { Ecology }}{x}$} & \multirow{2}{*}{$\frac{\begin{array}{c}\text { Econo- } \\
\text { mics }\end{array}}{\mathrm{x}}$} & \multirow{2}{*}{$\frac{\text { Policy }}{\mathrm{x}}$} & \multirow{2}{*}{$\begin{array}{l}\text { Content and interdisciplinary basis } \\
\text { Introduction into the Special Feature and description of } \\
\text { conceptual background, research questions, and key } \\
\text { assumptions. Short summary of all contributions in } \\
\text { Special Feature. }\end{array}$} \\
\hline 1 & $\begin{array}{l}\text { Sustainable Land-Use Practices in European } \\
\text { Mountain Regions under Global Change: an } \\
\text { Integrated Research Approach (Huber et al. 2013a) }\end{array}$ & & & & \\
\hline 2 & $\begin{array}{l}\text { Dynamics of Forage Production in Pasture- } \\
\text { woodlands of the Swiss Jura Mountains under } \\
\text { Projected Climate Change Scenarios (Gavazov et al. } \\
\text { 2013) }\end{array}$ & $\mathrm{x}$ & & & $\begin{array}{l}\text { Soil transplantation experiment along an altitudinal } \\
\text { gradient combined with landscape modeling in the case } \\
\text { study region Jura. The study shows the buffering potential } \\
\text { of landscape diversity against climate change impacts. }\end{array}$ \\
\hline 3 & $\begin{array}{l}\text { A Contextual Analysis of Land-Use and Vegetation } \\
\text { Changes in Two Wooded Pastures in the Swiss Jura } \\
\text { Mountains (Chételat et al. 2013) }\end{array}$ & $\mathrm{x}$ & $\mathrm{x}$ & $\mathrm{x}$ & $\begin{array}{l}\text { Combination of historical land-use chronicles with aerial } \\
\text { images to perform spatial statistics in the Jura. Reveals } \\
\text { importance of land-use history, e.g., politics and climate, } \\
\text { for the interaction of land-use and vegetation dynamics. }\end{array}$ \\
\hline 4 & $\begin{array}{l}\text { Past and future landscape dynamics in pasture- } \\
\text { woodlands of the Swiss Jura Mountains under } \\
\text { climate change (Peringer et al. 2013) }\end{array}$ & $\mathrm{x}$ & $\mathrm{x}$ & & $\begin{array}{l}\text { Retrospective (Middle Ages) and scenario based ( } 2100) \\
\text { simulations of silvopastoral landscape under climate } \\
\text { change. Shows the emergence of a complex landscape } \\
\text { mosaic through climate and land-use change. }\end{array}$ \\
\hline 5 & $\begin{array}{l}\text { Modeling Social-Ecological Feedback Effects in the } \\
\text { Implementation of Payments for Environmental } \\
\text { Services in Pasture-Woodlands (Huber et al. 2013c) }\end{array}$ & $\mathrm{x}$ & $\mathrm{x}$ & $\mathrm{x}$ & $\begin{array}{l}\text { Combination of mechanistic vegetation model with a } \\
\text { socioeconomic land-use model and policy network } \\
\text { analysis. Study bridges plot-based vegetation dynamics } \\
\text { with policy developments in the context of payments for } \\
\text { ecosystem services. }\end{array}$ \\
\hline 6 & $\begin{array}{l}\text { Constructing Consistent Multiscale Scenarios by } \\
\text { Transdisciplinary Processes: the Case of Mountain } \\
\text { Regions Facing Global Change (Brand et al. 2013) }\end{array}$ & & $\mathrm{x}$ & $\mathrm{x}$ & $\begin{array}{l}\text { Transdisciplinary scenario development with local } \\
\text { stakeholders. The study exemplifies the construction of } \\
\text { multiscale scenarios in a complex human-environmental } \\
\text { systems perspective. }\end{array}$ \\
\hline 7 & $\begin{array}{l}\text { Trade-Offs between Ecosystem Services in a } \\
\text { Mountain Region (Briner et al. 2013b) }\end{array}$ & $\mathrm{x}$ & $\mathrm{x}$ & & $\begin{array}{l}\text { Combination of forest landscape and socioeconomic } \\
\text { land-use models to assess trade-offs in the provision of } \\
\text { ecosystem services under climate change. Trade-offs } \\
\text { depend very much on the underlying structural } \\
\text { assumptions, e.g. farm/forest structures. }\end{array}$ \\
\hline 8 & $\begin{array}{l}\text { Combining Policy Network and Model-Based } \\
\text { Scenario Analyses: An Assessment of Future } \\
\text { Ecosystem Goods and Services in Swiss Mountain } \\
\text { Regions (Hirschi et al. 2013) }\end{array}$ & $\mathrm{x}$ & $\mathrm{x}$ & $\mathrm{x}$ & $\begin{array}{l}\text { Integration of policy network analysis with model-based } \\
\text { scenario analysis in the case study region Visp. Study } \\
\text { shows the importance of concomitant policy changes in } \\
\text { the context of payments for ecosystem services. }\end{array}$ \\
\hline 9 & $\begin{array}{l}\text { Integrating Expert Knowledge into Mapping } \\
\text { Ecosystem Services Trade-offs for Sustainable Forest } \\
\text { Management (Grêt-Regamey et al. 2013) }\end{array}$ & & $\mathrm{x}$ & $\mathrm{x}$ & $\begin{array}{l}\text { Integrating expert knowledge in a Bayesian network } \\
\text { model that maps forest ecosystem services trade-offs and } \\
\text { synergies. The mutual learning process from scientists and } \\
\text { experts resulted in a spatial explicit valuation of } \\
\text { ecosystem services. }\end{array}$ \\
\hline 10 & $\begin{array}{l}\text { Sustainable Land Use in Mountain Regions Under } \\
\text { Global Change: Synthesis Across Scales and } \\
\text { Disciplines (Huber et al. 2013b) }\end{array}$ & $\mathrm{x}$ & $\mathrm{x}$ & $\mathrm{x}$ & $\begin{array}{l}\text { Synthesis across regions, disciplines (experiments, } \\
\text { modeling, network analysis), and scales (plot to region } \\
\text { scale). Describes the underlying patterns in the case study } \\
\text { regions (nonlinearity, heterogeneity, trade-offs, and } \\
\text { feedbacks) and suggests policy options. }\end{array}$ \\
\hline
\end{tabular}

diversity of aspects influencing the experienced publication process and suited the limited number of 10 cases. In grounded theory, concepts and patterns are derived from empirical data, e.g., text, drawings, video or audio recordings, as opposed to using a theory as starting point. Following this rationale, we started with the influence factors identified within each story wall. Because we aimed at being understandable to researchers who might use the analysis to improve other interdisciplinary publishing processes, we followed the approach of substantive theorizing, which is opposed to aiming at connecting to a specific discipline's concepts and current debate, i.e., formal theorizing (Glaser and Strauss 1967). Thus, we used codes that correspond to the language of interdisciplinary researchers. For coding, we clustered similar factors to groups and described them in a more general and paraphrased way. To reground our interpretations in the empirical data, we wrote a short story for each paper, which related the coded factors to each paper's context (see Appendix 2 ). To review the 10 story walls and to analyze the factors in the process of interdisciplinary publishing, we collected all story walls in the same design (Fig. 1). Using constant comparisons across stories and between codes and story walls (Corbin and Strauss 2008), we refined and reformulated the coded factors. At this stage, we realized that in most cases success factors and barriers were actually positive or negative expressions of the same factor. 
Finally, we categorized the resulting set of 10 factors into four major groups of resources. This structure served to clarify how the resource groups can be used to support or hinder interdisciplinary publishing (see Table 2).

Fig. 1. Storywalls of the 10 "Mountland" papers representing the process of publishing the Special Feature (numbers refer to the factors described in Table 2).

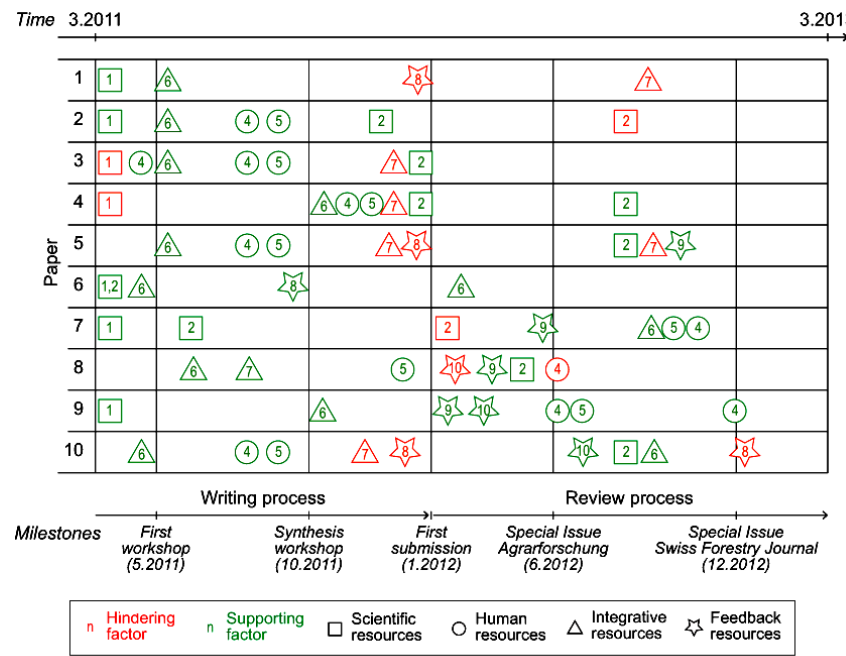

\section{RESULTS}

Table 2 summarizes and describes the 10 resulting factors. They are grouped into scientific resources, human resources, integrative resources, and feedback resources. Each factor can hinder or support interdisciplinary publishing, depending on the frame conditions described in the respective cells. Figure 1 summarizes the story walls of the 10 published papers. The numbers indicate the most important hindering (red) or supporting (green) factors. The story wall of each paper is explained in more detail in Appendix 2.

\section{Scientific resources}

Scientific resources that influenced the publication process include previous joint research and manuscripts being written in parallel by the same authors. Previous joint research (factor 1) means that the process of writing interdisciplinary papers can build on previous interdisciplinary research collaboration. It is a supporting factor if interdisciplinary collaborations are established before manuscript writing starts. For two out of 10 Mountland manuscripts, this was not the case. Interdisciplinary links between different research projects had actually been planned in the initial research framework. These links, however, were not always established or not completed successfully during the project. Papers 3 and 4, for instance, suffered from the fact that the associated $\mathrm{PhD}$ student had to quit for health reasons and model input for interdisciplinary research was missing (see Appendix 2). Different manuscripts written in parallel by the same authors (factor 2) turned out to be a supporting factor in most cases, in spite of the additional workload. They encompassed, for example, articles for stakeholder-oriented journals or different articles for the same Special Feature in which the researchers were involved as well. Writing manuscripts in parallel helped to clarify the manuscripts' main messages, to focus each manuscript, and to avoid redundancy. In the case of paper 2, a parallel manuscript hindered the process, however: a figure could not be used in the interdisciplinary manuscript because it was based on data of a publication written in parallel, which was not ready to be published yet.

\section{Human resources}

In terms of human resources, the main factors influencing the interdisciplinary publishing process were coordination, flexibility with respect to time and resources, and team composition. A project coordinator (factor 3) with preference for a particular disciplinary perspective on an issue hinders the process. A coordinator supports the process if (s)he is open to and interested in the different disciplinary perspectives and has the time and flexibility to identify and discuss topics requiring interdisciplinary collaboration. The flexibility (factor 4) to allocate additional workforce and money to specific aspects of developing an interdisciplinary manuscript or even to include or hire additional researchers was another important supporting factor. For papers 2,3 , and 4, for example, an additional research assistant and an additional postdoctoral researcher were able to catch up the missing work of the PhD student who quit. For paper 5, a master student performed modeling tasks to adjust the existing model to another region. For the synthesis of the project (paper 10), the flexibility of the different postdoctoral researchers and professors allowed pulling together the necessary information. In contrast, manuscripts that are locked in and get no additional input or know-how from outside because of missing time resources hinder the publication of interdisciplinary research. A successful revision of paper 7 could not be achieved until an additional author was able to resolve the lock in of previous versions of the manuscript. Finally, the composition of a team (factor 5) and the presence of efficiently collaborating researchers from different disciplines with different roles turned out to be an important aspect in publishing interdisciplinary research. This includes, but is not limited to, the availability of senior researchers and professors with sophisticated disciplinary backgrounds who can afford to and are interested in taking part in such processes.

\section{Integrative resources}

Integrative resources influencing interdisciplinary publishing cover the vision of integration and the timing of results. The vision of integration (factor 6) means that a project team arrives at a joint vision about a synthesis linking and integrating disciplinary and interdisciplinary research and an appropriate form of publication. Both the vision of the synthesis and the choice of the journal were collectively deliberated on at the first workshop (May 2011), together with the concepts of the single interdisciplinary contributions (see Fig. 1). For most of the papers, the joint vision and the identified topics triggered the work on an actual manuscript. The vision also allowed for an active exchange of ideas between the groups of authors, and facilitated findings to be aligned within the existing research framework. Moreover, the vision of the synthesis focused the search for an adequate journal, which otherwise would have been difficult. Once manuscript writing started, the timing of results (factor 7) turned out to be a main hindering factor. Papers 1, 3, 4, 5, and 10 all were delayed because they relied on results published in one of the other papers. Only in paper 8 was this not a problem because 
Table 2. Most important factors supporting or hindering the process of publishing interdisciplinary research identified in "Mountland."

\begin{tabular}{|c|c|c|c|}
\hline & Factor & ... support(s) interdisciplinary publishing ... & $\begin{array}{l}\text {... hinder(s) interdisciplinary publishing } \\
\ldots\end{array}$ \\
\hline \multirow[t]{3}{*}{ Scientific resources } & $\begin{array}{l}\text { 1. Previous joint research } \\
\ldots\end{array}$ & $\begin{array}{l}\ldots \text { if the process of joint disciplinary and } \\
\text { interdisciplinary research has been established before } \\
\text { the writing of interdisciplinary manuscripts started. }\end{array}$ & $\begin{array}{l}\ldots \text { if research providing fundamental } \\
\text { links between disciplines has not been } \\
\text { planned or has not been completed } \\
\text { successfully. }\end{array}$ \\
\hline & $\begin{array}{l}\text { 2. Manuscripts written in } \\
\text { parallel } \\
\text { by the same } \\
\text { authors ... }\end{array}$ & $\begin{array}{l}\text {... if papers on the same or similar research written } \\
\text { earlier or in parallel, targeting a different audience or } \\
\text { dealing with a different issue help to clarify a papers' } \\
\text { message (in the present case mostly papers in applied } \\
\text { forestry and agriculture, and other papers of the } \\
\text { Special Feature) }\end{array}$ & $\begin{array}{l}\ldots \text { if results needed for the } \\
\text { interdisciplinary paper are not yet } \\
\text { published, but should be published first to } \\
\text { adequately value the individual } \\
\text { researchers' merits. }\end{array}$ \\
\hline & & & $\begin{array}{l}\ldots \text { if results needed for the } \\
\text { interdisciplinary paper are already } \\
\text { published in an individual paper, e.g., } \\
\text { leading to a reviewer's comment that the } \\
\text { added value of a manuscript was missing. }\end{array}$ \\
\hline \multirow[t]{3}{*}{ Human resources } & 3. Coordination ... & $\begin{array}{l}\ldots \text { if the coordinator has (a) an interdisciplinary, } \\
\text { balanced, and encompassing view on the project, (b) } \\
\text { enough time and flexibility to identify topics } \\
\text { requiring interdisciplinary collaboration, and (c) is } \\
\text { able to serve as source for exchange of ideas. }\end{array}$ & $\begin{array}{l}\ldots \text { if the coordinator has preferences for } \\
\text { specific disciplines. }\end{array}$ \\
\hline & 4. Flexibility ... & $\begin{array}{l}\text {... if (a) researchers have freedom to allocate more } \\
\text { time to specific aspects of an interdisciplinary } \\
\text { manuscript than originally planned, (b) additional } \\
\text { researchers can be hired or funding can be moved } \\
\text { within and between groups, and (c) additional } \\
\text { scientific input can be provided, e.g., through } \\
\text { Bachelor or Master thesis. }\end{array}$ & $\begin{array}{l}\text { ".. if authors of the manuscript are } \\
\text { "locked in" and do not have know-how, } \\
\text { time, and funding to accomplish a } \\
\text { necessary refocusing or advancement of } \\
\text { an interdisciplinary manuscript. }\end{array}$ \\
\hline & $\begin{array}{l}\text { 5. Composition } \\
\text { of team ... }\end{array}$ & $\begin{array}{l}\ldots \text { if senior researchers with sophisticated } \\
\text { disciplinary backgrounds can afford to, and are } \\
\text { interested in collaboratively working on the synthesis } \\
\text { of results. }\end{array}$ & \\
\hline \multirow[t]{2}{*}{$\begin{array}{l}\text { Integrative } \\
\text { resources }\end{array}$} & 6. Vision of integration ... & $\begin{array}{l}\ldots \text { if there is a sound concept on how to link } \\
\text { disciplinary knowledge and allocate the } \\
\text { corresponding resources (also resources to rework } \\
\text { papers after reviews). } \\
\ldots \text { if the vision fits into an interdisciplinary journal. }\end{array}$ & $\begin{array}{l}\ldots \text { in case of ad hoc linkage of existing } \\
\text { work without planning of integration and } \\
\text { resources. } \\
\ldots \text { if the vision complicates the choice of } \\
\text { an adequate journal to publish } \\
\text { interdisciplinary research. }\end{array}$ \\
\hline & $\begin{array}{l}\text { 7. Timing of } \\
\text { results } \ldots\end{array}$ & $\begin{array}{l}\text {... if integration of results and inputs from one } \\
\text { discipline (or existing manuscript) in another } \\
\text { discipline (or manuscript) is temporally coordinated. }\end{array}$ & $\begin{array}{l}\ldots \text { if results from other projects/papers } \\
\text { are not ready to be integrated or quoted, } \\
\text { e.g., because the projects/papers are } \\
\text { delayed or do not provide the expected } \\
\text { results. }\end{array}$ \\
\hline \multirow[t]{3}{*}{ Feedback resources } & $\begin{array}{l}\text { 8. Internal } \\
\text { reviews ... }\end{array}$ & $\begin{array}{l}\ldots \text { if the internal review of manuscript before } \\
\text { submission is efficiently organized (depending on the } \\
\text { subject matter, internal reviews can thereby go } \\
\text { beyond the project members). }\end{array}$ & $\begin{array}{l}\text {... if coauthors, e.g., for lack of time, only } \\
\text { review and comment their disciplinary } \\
\text { partial contribution to the paper rather } \\
\text { than the interdisciplinary manuscript as a } \\
\text { whole. }\end{array}$ \\
\hline & $\begin{array}{l}\text { 9. Subject editors } \\
\text { (if any) ... }\end{array}$ & $\begin{array}{l}\ldots \text { if (in addition to the journal's editor) they are } \\
\text { familiar with the project and know how to interpret } \\
\text { reviews of an individual paper in the context of all } \\
\text { interdisciplinary papers and of the project as a } \\
\text { whole. }\end{array}$ & \\
\hline & 10. External reviewers ... & $\begin{array}{l}\ldots \text { if they are open minded, i.e., review the } \\
\text { disciplinary aspect based on their expertise while } \\
\text { keeping the interdisciplinary approach and context in } \\
\text { mind. As a result, the interdisciplinary quality of the } \\
\text { manuscript is improved. }\end{array}$ & $\begin{array}{l}\ldots \text { if they review the manuscript from the } \\
\text { perspective of their disciplinary expertise } \\
\text { only, ignoring interdisciplinary efforts. }\end{array}$ \\
\hline
\end{tabular}


there was a clear plan on how to integrate disciplinary approaches and their results.

\section{Feedback resources}

Interdisciplinary publishing often depends on feedback from internal reviews, subject editors, and external reviewers. The internal review process (factor 8) hindered the publication of papers 1,5 , and 10 . Several coauthors who were strongly pressed for time reviewed only their discipline-specific section contributions to the paper, but not the paper as a whole, which entailed the danger of ending with "committee papers" that lack integration. Subject editors (factor 9), being familiar with Mountland as well as with doing and publishing interdisciplinary research, strongly supported the publication process. In contrast to some external reviewers, the subject editors recognized the interdisciplinary potential of papers $5,7,8$, and 9 . They helped the authors to clarify and elaborate the interdisciplinary contribution and to align the reviewers' comments with the authors' options to adapt the manuscript. This was not aimed at lowering the bar for getting accepted, because the ultimate decision on acceptance of the papers was made by the editor-inchief of the journal, not the subject editors. External reviewers' inputs (factor 10) helped interdisciplinary publishing and substantially improved all manuscripts, particularly papers 9 and 10. In the case of paper 8, however, the external reviewers hindered the process by seeing no added value in the interdisciplinary effort and by asking the authors to focus the manuscript on one discipline only.

\section{DISCUSSION}

The first of the six recommendations on interdisciplinary publishing identified in the introduction says that "[j]ournal editors and editorial boards should encourage interdisciplinary contributions" (NAS/NAE/IOM 2005:201). This was helped greatly by the fact that Ecology and Society is one of the few journals that target exactly this kind of research. In addition, we found that subject editors (factor 9) and external reviewers (factor 10) who are open-minded toward interdisciplinary research are of crucial importance.

According to the second recommendation, deadlines or time constraints should be used to focus the group (Gooch 2005). Our analysis adds to this recommendation the experience that in spite of good time planning and rigorous monitoring of the writing activities, many things can develop in an unforeseen way, such as researchers quitting the project. We therefore recommend building flexibility in the publishing process in terms of money, time, and people (factor 4).

The third recommendation states that a basic understanding of other disciplines is required for collaborative writing (Gooch 2005). Our analysis suggests a number of additional factors. Previous joint research facilitates such mutual understanding and fosters interdisciplinary publishing (factor 2). The composition of the team is crucial (factor 5): A good team will be selfreinforcing because it promotes fruitful collaboration and real teamwork. The participation of senior researchers who are more experienced in research and publishing, who are ready to deal with other disciplines, and who can place their contributions within a broader framework is a valuable component. $\mathrm{PhD}$ students may be less well prepared to do so because they mostly have to develop a disciplinary identity first. Also, joint visions of integration are required (factor 6). This does not need to be a single unifying big vision across the entire project. In the case of Mountland, different forms of integration were used in the various papers and stages: common group learning, modeling, negotiation among experts, or integration by a leader (Rossini and Porter 1979). However, the predominant form of integration was using models as integrative frameworks that asked for data and indicators that could be exchanged between groups. Furthermore, a coordinator who is flexible and interested in integration and interdisciplinarity is very valuable (factor 3). Finally, researchers should be prepared to review more than their own sections in jointly written papers (factor 8).

The fourth recommendation asks participants to recognize that the stages of paper writing, i.e., outline, drafting of parts, and revision, can be accomplished in a variety of ways (Ede and Lunsford 1990, Gooch 2005). Our analysis does not contradict this recommendation. We found as many ways of joint writing as we had papers. However, based on the central role of the vision of integration we would specify that once the vision is clear and the form of integration agreed on, the exact manner in which collective writing is organized may indeed be less relevant.

According to the fifth recommendation, project researchers should aim at publishing both disciplinary and interdisciplinary insights (Kueffer et al. 2007). Our analysis makes this recommendation more specific by suggesting that manuscripts be written in parallel: If an author or a group of authors prepares several manuscripts on the same issue for different audiences in parallel, this helps clarifying each paper's specific message (factor 2 ). On the other hand, if several groups of authors publish disciplinary and interdisciplinary insights in parallel, they may have to consider the points in time at which the results of other parts are provided and ready for publication (factor 7). This may be important not only for practical, but also for strategic, reasons: New disciplinary insights often first need to be published in a disciplinary journal to promote the highest possible scientific impact.

The sixth recommendation states that projects should also publish methodological insights gained through the interdisciplinary research process (Kueffer et al. 2007). With respect to the publishing part, this is what we tried to achieve with the present paper.

\section{CONCLUSION: AN IDEAL-TYPICAL PUBLICATION PROCESS}

We have attempted to assess the elements of an ideal-typical story wall summarizing the success factors for publishing a team's interdisciplinary efforts. We call the story wall "ideal-typical" (Weber 1962) because it represents a simplified summary of the crucial process factors, accentuating the most relevant among them. Figure 2 illustrates the most essential success factors of such an ideal-typical publication process, grouped as scientific resources, human resources, integrative resources, and feedback resources.

In terms of scientific resources, the first factor that supports publishing interdisciplinary research is previous research collaboration. Preferably, the conceptual background of the underlying research has methodological interfaces that allow for 
Fig. 2. An ideal-typical storywall to publish interdisciplinary research (numbers refer to the factors described in Table 2).
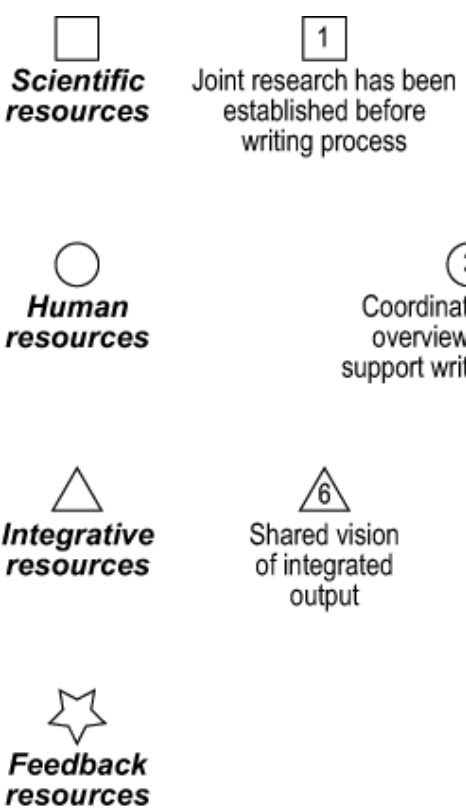

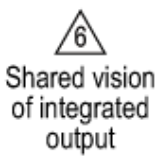

(3)

Coordination keeps overview and can support writing process

2

Disciplinary background has been published
Parallel manuscripts help to focus

the writing process

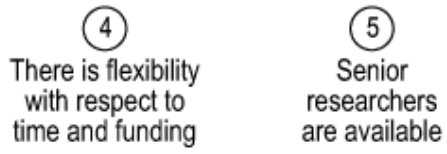

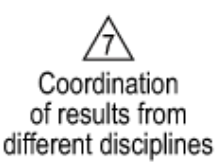

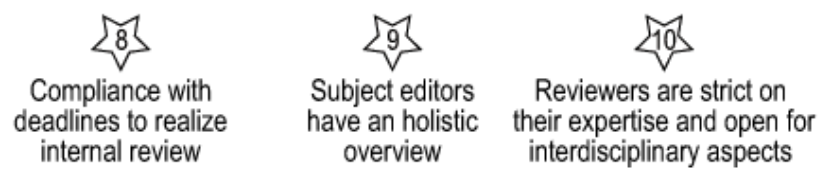

Submission

Journal review process

an effective integration of research findings from different scientific disciplines. In addition, basic information on the methodologies' disciplinary background should already be published, so that it can be referred to. Moreover, writing manuscripts in parallel for different audiences helps to clarify a paper's message (factor 2). With respect to human resources, the coordinator represents the focal point for successfully publishing interdisciplinary research (factor 3). Ideally, a research coordinator is familiar with ongoing disciplinary and interdisciplinary research, and can actively support the writing process. Within each project, there should be time and funding specifically reserved for the review process to improve and possibly refocus the initial manuscripts (factor 4). The availability of experienced senior scientists and professors (factor 5) with a strong disciplinary background forms another essential part of an ideal-typical process for publishing interdisciplinary research. In terms of integrative resources, it is key to jointly deliberate and decide on the adequate form(s) of integration and to develop a joint vision of the integrated output (factor 6). This vision in turn forms an essential starting point for the process of publishing interdisciplinary research. Another crucial task is to coordinate the results from different disciplines that have to be integrated over time (factor 7). In terms of feedback resources, projects should allocate time and resources to review the parts of the papers written by coauthors (factor 8 ). Furthermore, a subject editor with a broad overview of the project, the involved disciplines, and the interdisciplinary merits (factor 9) needs to find excellent reviewers with strong disciplinary expertise who are open-minded regarding interdisciplinary efforts (factor 10).

To successfully implement such an ideal-typical publication process, long-term planning is needed. This is so because some of the factors hindering or supporting interdisciplinary publishing are defined already at the stage of writing the research proposal, rather than when writing the papers based on the research results. Thus, planning a joint synthesis in a Special Feature may be a stimulating incentive for different research groups and disciplines to take part in an interdisciplinary process right from the start.

We freely admit that the success factors for interdisciplinary publishing that we propose here for the ideal-typical story wall are based on an exploratory analysis of one single case, i.e., the Ecology and Society Special Feature of the research project Mountland. We assume that a project's structural characteristics, such as the way disciplinary research efforts are integrated, the number and kind of the disciplines involved, and the way the project is funded, strongly influence the relevance and practical importance of these factors. Thus, a comparative study of different interdisciplinary publishing processes would allow for valuing and generalizing the individual factors by relating them to structural characteristics of different interdisciplinary research projects. However, with the caveat that the factors may have a different relevance in a different project context, we strongly suggest that they should at least be inspiring and useful for planning and undertaking interdisciplinary publishing processes in a more sophisticated way.

Responses to this article can be read online at: http://www.ecologyandsociety.org/issues/responses. $\mathrm{php} / 7448$ 


\section{Acknowledgments:}

This work was supported by the CCES (Competence Center Environment and Sustainability of the ETH Domain, Switzerland) as part of the MOUNTLAND project and by the Stiftung Mercator Schweiz. We thank the two anonymous reviewers for their helpful comments.

\section{LITERATURE CITED}

Akimowicz, M., M.-B. Magrini, A. Ridier, J.-E. Bergez, and D. Requier-Desjardins. 2013. What influences farm size growth? An illustration in Southwestern France. Applied Economic Perspectives and Policy 35(2):242-269. http://dx.doi.org/10.1093/ aepp/ppt008

Allen, L., J. Scott, A. Brand, M. Hlava, and M. Altman. 2014. Publishing: credit where credit is due. Nature 508(7496):312-313. http://dx.doi.org/10.1038/508312a

Barbeito, I., M. A. Dawes, C. Rixen, J. Senn, and P. Bebi. 2012. factors driving mortality and growth at treeline: a 30-year experiment of 92000 conifers. Ecology 93(2):389-401. http://dx. doi.org/10.1890/11-0384.1

Bennett, M. L., H. Gadlin, and S. Levine-Finley. 2010. Collaboration \& team science: a field guide. NIH Office of the Ombudsman, Center for Cooperative Resolution, Bethesda, Maryland, USA.

Bergmann, M., T. Jahn, T. Knobloch, W. Krohn, C. Pohl, and E. Schramm. 2012. Methods for transdisciplinary research - a primer for practice. Main Campus Verlag, Frankfurt, Germany.

Bozeman, B., D. Fay, and C. P. Slade. 2013. Research collaboration in universities and academic entrepreneurship: thestate-of-the-art. Journal of Technology Transfer 38(1):1-67. http:// dx.doi.org/10.1007/s10961-012-9281-8

Brand, F. S., R. Seidl, Q. B. Le, J. M. Brändle, and R. W. Scholz. 2013. Constructing consistent multiscale scenarios by transdisciplinary processes: the case of mountain regions facing global change. Ecology and Society 18(2): 43. http://dx.doi. org/10.5751/ES-04972-180243

Briner, S., C. Elkin, and R. Huber. 2013a. Evaluating the relative impact of climate and economic changes on forest and agricultural ecosystem services in mountain regions. Journal of Environmental Management 129:414-422. http://dx.doi.org/10.1016/ j.jenvman.2013.07.018

Briner, S., C. Elkin, R. Huber, and A. Grêt-Regamey. 2012. Assessing the impacts of economic and climate changes on landuse in mountain regions: a spatial dynamic modeling approach. Agriculture, Ecosystems \& Environment 149:50-63. http://dx.doi. org/10.1016/j.agee.2011.12.011

Briner, S., R. Huber, P. Bebi, C. Elkin, D. R. Schmatz, and A. Grêt-Regamey. 2013b. Trade-offs between ecosystem services in a mountain region. Ecology and Society 18(3): 35. http://dx.doi. org/10.5751/ES-05576-180335

Cheruvelil, K. S., P. A. Soranno, K. C. Weathers, P. C. Hanson, S. J. Goring, C. T. Filstrup, and E. K. Read. 2014. Creating and maintaining high-performing collaborative research teams: the importance of diversity and interpersonal skills. Frontiers in Ecology and the Environment 12(1):31-38. http://dx.doi. org/10.1890/130001

Chételat, J., M. Kalbermatten, K. S. M. Lannas, T. Spiegelberger, J. B. Wettstein, F. Gillet, A. Peringer, and A. Buttler. 2013. A contextual analysis of land-use and vegetation changes in two wooded pastures in the Swiss Jura Mountains. Ecology and Society 18(1): 39. http://dx.doi.org/10.5751/ES-05287-180139

Corbin, J. M., and A. L. Strauss. 2008. Basics of qualitative research: techniques and procedures for developing grounded theory. Third edition. Sage, Thousand Oaks, California, USA.

Dawes, M. A., S. Hättenschwiler, P. Bebi, F. Hagedorn, I. T. Handa, C. Körner, and C. Rixen. 2011. Species-specific tree growth responses to 9 years of $\mathrm{CO}_{2}$ enrichment at the alpine treeline. Journal of Ecology 99(2):383-394. http://dx.doi. org/10.1111/j.1365-2745.2010.01764.X

Ede, L. S., and A. A. Lunsford. 1990. Singular texts, plural authors perspectives on collaborative writing. Southern Illinois University Press, Carbondale, Illinois, USA.

Eilmann, B., M. Dobbertin, and A. Rigling. 2013. Growth response of Scots pine with different crown transparency status to drought release. Annals of Forest Science 70(7):685-693. http:// dx.doi.org/10.1007/s13595-013-0310-Z

Elkin, C., B. Reineking, C. Bigler, and H. Bugmann. 2012. Do small-grain processes matter for landscape scale questions? Sensitivity of a forest landscape model to the formulation of tree growth rate. Landscape Ecology 27(5):697-711. http://dx.doi. org/10.1007/s10980-012-9718-3

Falk-Krzesinski, H. J., N. Contractor, S. M. Fiore, K. L. Hall, C. Kane, J. Keyton, J. T. Klein, B. Spring, D. Stokols, and W. Trochim. 2011. Mapping a research agenda for the science of team science. Research Evaluation 20(2):145-158. http://dx.doi. org/10.3152/095820211X12941371876580

Frodeman, R., J. T. Klein, and C. Mitcham, editors. 2010. The Oxford handbook of interdisciplinarity. Oxford University Press, Oxford, UK.

Gavazov, K., T. Spiegelberger, and A. Buttler. 2014. Transplantation of subalpine wood-pasture turfs along a natural climatic gradient reveals lower resistance of unwooded pastures to climate change compared to wooded ones. Oecologia 174 (4):1425-1435. http://dx.doi.org/10.1007/s00442-013-2839-9

Gavazov, K. S., A. Peringer, A. Buttler, F. Gillet, and T. Spiegelberger. 2013. Dynamics of forage production in pasturewoodlands of the Swiss Jura Mountains under projected climate change scenarios. Ecology and Society 18(1): 38. http://dx.doi. org/10.5751/ES-04974-180138

Gazni, A., and F. Didegah. 2011. Investigating different types of research collaboration and citation impact: a case study of Harvard University's publications. Scientometrics 87(2):251-265. http://dx.doi.org/10.1007/s11192-011-0343-8

Glaser, B. G., and A. L. Strauss. 1967. The discovery of grounded theory: strategies for qualitative research. Fourth edition. de Gruyter, New York, New York, USA. 
Gooch, J. C. 2005. The dynamics and challenges of interdisciplinary collaboration: a case study of "cortical depth of bench" in group proposal writing. IEEE Transactions on Professional Communication 48(2):177-190. http://dx.doi. org/10.1109/TPC.2005.849646

Grêt-Regamey, A., S. H. Brunner, J. Altwegg, M. Christen, and P. Bebi. 2013. Integrating expert knowledge into mapping ecosystem services trade-offs for sustainable forest management. Ecology and Society 18(3): 34. http://dx.doi.org/10.5751/ ES-05800-180334

Hall, K. L., D. Stokols, B. A. Stipelman, A. L. Vogel, A. Feng, B. Masimore, G. Morgan, R. P. Moser, S. E. Marcus, and D. Berrigan. 2012. Assessing the value of team science a study comparing center- and investigator-initiated grants. American Journal of Preventive Medicine 42(2):157-163. http://dx.doi. org/10.1016/j.amepre.2011.10.011

Heemskerk, M., K. Wilson, and M. Pavao-Zuckerman. 2003. Conceptual models as tools for communication across disciplines. Conservation Ecology 7(3): 8. [online] URL: http://www.consecol. org/vol7/iss3/art8/

Hicks, D. M., and S. J. Katz. 1996. Where is science going? Science, Technology \& Human Values 21(4):379-406. http://dx.doi. org/10.1177/016224399602100401

Hirsch Hadorn, G., H. Hoffmann-Riem, S. Biber-Klemm, W. Grossenbacher-Mansuy, D. Joye, C. Pohl, U. Wiesmann, and E. Zemp, editors. 2008. Handbook of transdisciplinary research. Springer, Berlin, Germany. http://dx.doi.org/10.1007/978-1-4020-6699-3

Hirschi, C., A. Widmer, S. Briner, and R. Huber. 2013. Combining policy network and model-based scenario analyses: an assessment of future ecosystem goods and services in Swiss mountain regions. Ecology and Society 18(2): 42. http://dx.doi.org/10.5751/ ES-05480-180242

Huber, R., P. Bebi, S. Briner, H. Bugmann, A. Buttler, A. GrêtRegamey, C. Hirschi, R. Scholz, W. Zimmermann, and A. Rigling. 2012b. Klimawandel und nachhaltige Landnutzung im Berggebiet. Agrarforschung Schweiz 3(7-8):340-345.

Huber, R., S. Briner, A. Peringer, S. Lauber, R. Seidl, A. Widmer, F. Gillet, A. Buttler, Q. Bao Le, and C. Hirschi. 2013c. Modeling social-ecological feedback effects in the implementation of payments for environmental services in pasture-woodlands. Ecology and Society 18(2): 41. http://dx.doi.org/10.5751/ ES-05487-180241

Huber, R., H. Bugmann, A. Buttler, and A. Rigling. $2013 a$. Sustainable land-use practices in European mountain regions under global change: an integrated research approach. Ecology and Society 18(3): 37. http://dx.doi.org/10.5751/ES-05375-180337

Huber, R., A. Rigling, P. Bebi, F. S. Brand, S. Briner, A. Buttler, C. Elkin, F. Gillet, A. Grêt-Regamey, C. Hirschi, H. Lischke, R. W. Scholz, R. Seidl, T. Spiegelberger, A. Walz, W. Zimmermann, and H. Bugmann. 2013b. Sustainable land use in mountain regions under global change: synthesis across scales and disciplines. Ecology and Society 18(3): 36. http://dx.doi. org/10.5751/ES-05499-180336

Huber, R., A. Walz, and A. Rigling. 2012a. Nachhaltige landund forstwirtschaft im Berggebiet: das forschungsprojekt
"Mountland." Schweizerische Zeitschrift für Forstwesen 163 (12):464-468. http://dx.doi.org/10.3188/szf.2012.0464

Jones, B. F., S. Wuchty, and B. Uzzi. 2008. Multi-university research teams: shifting impact, geography, and stratification in science. Science 322(5905):1259-1262. http://dx.doi.org/10.1126/ science. 1158357

Katz, J. S., and B. R. Martin. 1997. What is research collaboration? Research Policy 26(1):1-18. http://dx.doi.org/10.1016/S0048-7333 (96)00917-1

Klein, J. T. 2010. A taxonomy of interdisciplinarity. Pages 15-30 in R. Frodeman, J. T. Klein, and C. Mitcham, editors. The Oxford handbook of interdisciplinarity. Oxford University Press, Oxford, UK.

Kueffer, C., G. Hirsch Hadorn, G. Bammer, L. van Kerkhoff, and C. Pohl. 2007. Towards a publication culture in transdisciplinary research. GAIA 16(1):22-26.

Kueffer, C., E. Underwood, G. Hirsch Hadorn, R. Holderegger, M. Lehning, C. Pohl, M. Schirmer, R. Schwarzenbach, M. Stauffacher, G. Wuelser, and P. Edwards. 2012. Enabling effective problem-oriented research for sustainable development. Ecology and Society 17(4): 8. http://dx.doi.org/10.5751/ES-05045-170408

McDonald, D., G. Bammer, and P. Dean. 2009. Research integration using dialogue methods. ANU Press, The Australian National University, Canberra, Australian Capital Territory, Australia.

National Academy of Sciences, National Academy of Engineering, and Institute of Medicine (NAS/NAE/IOM). 2005. Facilitating interdisciplinary research. National Academies Press, Washington, D.C., USA.

O'Rourke, M., and S. Crowley. 2013. Philosophical intervention and cross-disciplinary science: the story of the Toolbox Project. Synthese 190(11):1937-1954. http://dx.doi.org/10.1007/s11229-012-0175$\mathrm{y}$

Peringer, A., S. Siehoff, J. Chételat, T. Spiegelberger, A. Buttler, and F. Gillet. 2013. Past and future landscape dynamics in pasture-woodlands of the Swiss Jura Mountains under climate change. Ecology and Society 18(3): 11. http://dx.doi.org/10.5751/ ES-05600-180311

Pohl, C. 2005. Transdisciplinary collaboration in environmental research. Futures 37(10):1159-1178. http://dx.doi.org/10.1016/j. futures.2005.02.009

Porac, J. F., J. B. Wade, H. M. Fischer, J. Brown, A. Kanfer, and G. Bowker. 2004. Human capital heterogeneity, collaborative relationships, and publication patterns in a multidisciplinary scientific alliance: a comparative case study of two scientific teams. Research Policy 33(4):661-678. http://dx.doi.org/10.1016/ $\underline{\text { S0048-7333(04)00015-0 }}$

Rigling, A., C. Bigler, B. Eilmann, E. Feldmeyer-Christe, U. Gimmi, C. Ginzler, U. Graf, P. Mayer, G. Vacchiano, P. Weber, T. Wohlgemuth, R. Zweifel, and M. Dobbertin. 2013. Driving factors of a vegetation shift from Scots pine to pubescent oak in dry Alpine forests. Global Change Biology 19(1):229-240. http:// dx.doi.org/10.1111/gcb.12038 
Rosenfield, P. L. 1992. The potential of transdisciplinary research for sustaining and extending linkages between the health and social sciences. Social Science \& Medicine 35(11):1343-1357. http://dx.doi.org/10.1016/0277-9536(92)90038-R

Rossini, F. A., and A. L. Porter. 1979. Frameworks for integrating disciplinary research. Research Policy 8(1):70-79. http://dx.doi. org/10.1016/0048-7333(79)90030-1

Seppelt, R., B. Fath, B. Burkhard, J. L. Fisher, A. Grêt-Regamey, S. Lautenbach, P. Pert, S. Hotes, J. Spangenberg, P. H. Verburg, and A. P. E. Van Oudenhoven. 2012. Form follows function? Proposing a blueprint for ecosystem service assessments based on reviews and case studies. Ecological Indicators 21:145-154. http:// dx.doi.org/10.1016/j.ecolind.2011.09.003

Smit, A. 2005. The facilitator's toolkit. Centre for Business in Society, University of Stellenbosch, Stellenbosch, South Africa.

Stokols, D., J. Fuqua, J. Gress, R. Harvey, K. Phillips, L. Baezconde-Garbanati, J. Unger, P. Palmer, M. A. Clark, S. M. Colby, G. Morgan, and W. Trochim. 2003. Evaluating transdisciplinary science. Nicotine \& Tobacco Research 5(suppl 1):S21-S39. http://dx.doi.org/10.1080/14622200310001625555

Stokols, D., K. L. Hall, B. K. Taylor, and R. P. Moser. 2008b. The science of team science: overview of the field and introduction to the supplement. American Journal of Preventive Medicine 35(2 suppl):S77-S89. http://dx.doi.org/10.1016/j.amepre.2008.05.002

Stokols, D., S. Misra, R. P. Moser, K. L. Hall, and B. K. Taylor. 2008a. The ecology of team science: understanding contextual influences on transdisciplinary collaboration. American Journal of Preventive Medicine 35(2):S96-S115. http://dx.doi.org/10.1016/ j.amepre.2008.05.003

Stvilia, B., C. C. Hinnant, K. Schindler, A. Worrall, G. Burnett, K. Burnett, M. M. Kazmer, and P. F. Marty. 2011. Composition of scientific teams and publication productivity at a national science lab. Journal of the American Society for Information Science and Technology 62(2):270-283. http://dx.doi.org/10.1002/ asi. 21464

Vogel, A. L., K. L. Hall, S. M. Fiore, J. T. Klein, L. M. Bennett, H. Gadlin, D. Stokols, L. C. Nebeling, S. Wuchty, K. Patrick, E. L. Spotts, C. Pohl, W. T. Riley, and H. J. Falk-Krzesinski. 2013. The team science toolkit: enhancing research collaboration through online knowledge sharing. American Journal of Preventive Medicine 45(6):787-789. http://dx.doi.org/10.1016/j. amepre.2013.09.001

Weber, M. 1962. Basic concepts in sociology. Citadel, New York, New York, USA.

Wiesmann, U., S. Biber-Klemm, W. Grossenbacher-Mansuy, G. Hirsch Hadorn, H. Hoffmann-Riem, D. Joye, C. Pohl, and E. Zemp. 2008. Enhancing transdisciplinary research: a synthesis in fifteen propositions. Pages 433-441 in G. Hirsch Hadorn, H. Hoffmann-Riem, S. Biber-Klemm, W. Grossenbacher-Mansuy, D. Joye, C. Pohl, U. Wiesmann, and E. Zemp, editors. Handbook of transdisciplinary research. Springer, Dordrecht, Netherlands. http://dx.doi.org/10.1007/978-1-4020-6699-3 29

Winowiecki, L., S. Smukler, K. Shirley, R. Remans, G. Peltier, E. Lothes, E. King, L. Comita, S. Baptista, and L. Alkema. 2011.
Tools for enhancing interdisciplinary communication. Sustainability: Science, Practice, \& Policy 7(1):4-80.

Wuchty, S., B. F. Jones, and B. Uzzi. 2007. The increasing dominance of teams in production of knowledge. Science 316 (5827):1036-1039. http://dx.doi.org/10.1126/science.1136099

Zurbriggen, N., J. E. M. S. Nabel, M. Teich, P. Bebi, and H. Lischke. 2014. Explicit avalanche-forest feedback simulations improve the performance of a coupled avalanche-forest model. Ecological Complexity 17:56-66. http://dx.doi.org/10.1016/j. ecocom.2013.09.002 
Appendix 1. Composition of "Mountland" research team (changes in status during project in brackets).

\begin{tabular}{|c|c|c|c|c|c|c|}
\hline & 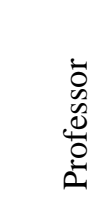 & 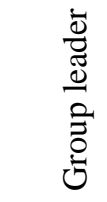 & 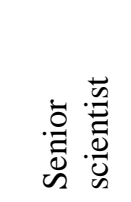 & 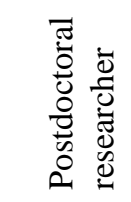 & 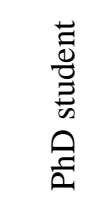 & 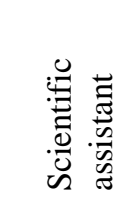 \\
\hline Bugmann Harald (Leader task 1) & $\mathrm{X}$ & & & & & \\
\hline Buttler Alexandre & $\mathrm{x}$ & & & & & \\
\hline Engel Stefanie (Leader task 3) & $\mathrm{x}$ & & & & & \\
\hline Grêt-Regamey Adrienne & $\mathrm{x}$ & & & & & \\
\hline Lehmann Bernard (Leader task 2) & $\mathrm{x}$ & & & & & \\
\hline Scholz Roland & $\mathrm{x}$ & & & & & \\
\hline Zimmermann Willi & $\mathrm{x}$ & & & & & \\
\hline Gillet François & $(\mathrm{x})$ & & $\mathrm{x}$ & & & \\
\hline Ingold Karin & $(\mathrm{x})$ & & $\mathrm{x}$ & & & \\
\hline Koellner Thomas & $(\mathrm{x})$ & & $\mathrm{x}$ & & & \\
\hline Lang Daniel & $(\mathrm{x})$ & & $\mathrm{x}$ & & & \\
\hline Walz Ariane & $(\mathrm{x})$ & & & $\mathrm{x}$ & & \\
\hline Bebi Peter & & $\mathrm{x}$ & & & & \\
\hline Hagedorn Frank & & $\mathrm{x}$ & & & & \\
\hline Rigling Andreas (Project leader) & & $\mathrm{x}$ & & & & \\
\hline Balsiger Jörg & & & $\mathrm{x}$ & & & \\
\hline Dobbertin Matthias & & & $\mathrm{x}$ & & & \\
\hline Le Quang Bao & & & $\mathrm{x}$ & & & \\
\hline Lischke Heike & & & $\mathrm{x}$ & & & \\
\hline Schmatz Dirk & & & $\mathrm{x}$ & & & \\
\hline Spiegelberger Thomas & & & $\mathrm{x}$ & & & \\
\hline Brand Fridolin & & & & $\mathrm{x}$ & & \\
\hline Chetelat Joel & & & & $\mathrm{x}$ & & \\
\hline Elkin Ché & & & & $\mathrm{x}$ & & \\
\hline Hirschi Christian & & & & $\mathrm{x}$ & & \\
\hline Huber Robert & & & & $\mathrm{x}$ & & \\
\hline Peringer Alexander & & & & $\mathrm{x}$ & & \\
\hline Seidl Roman & & & & $\mathrm{x}$ & & \\
\hline Brändle Julia & & & & & $\mathrm{x}$ & \\
\hline Briner Simon & & & & & $\mathrm{x}$ & \\
\hline Gavazov Konstantin & & & & & $\mathrm{x}$ & \\
\hline Giuggiola Arnaud & & & & & $\mathrm{x}$ & \\
\hline Lannas Katy & & & & & $\mathrm{x}$ & \\
\hline Teich Michaela & & & & & $\mathrm{x}$ & \\
\hline Widmer Alexander & & & & & $\mathrm{x}$ & \\
\hline Zurbriggen Natalie & & & & & $\mathrm{x}$ & \\
\hline Kalbermatten Michael & & & & & & $\mathrm{x}$ \\
\hline
\end{tabular}


Appendix 2. Storylines.

Paper 1: Sustainable land-use practices in European mountain regions under global change: An integrated research approach (accepted 29.10.2012).

The introduction to the Special Feature was based on the original «Mountland had been funded by the CCES in 2008. The workflow (Figure 2 in the manuscript) had been used to present «Mountland at several conferences and meetings before the idea of this synthesis was developed (1). In addition, the vision of the synthesis developed at the workshop in May 2011 helped to focus the outline and content of the manuscript (6). The researchers agreed on the added value of the Special Feature to base all contributions on either inter- or transdisciplinary collaborations. The internal review (8), however, was a difficult task for two reasons: a) the co-authors (and leaders of the project) had limited time resources to review the text; and b) the other authors were fully involved in the preparation of their own contribution to the Special Feature. As a consequence, they did not carefully review the summary of their own manuscripts in the introduction. A further challenge was that the summaries of the special feature's papers had to be written before all of the papers were ready for submission (7).

Paper 2: Dynamics of forage production in pasture-woodlands of the Swiss Jura Mountains under projected climate change scenarios (accepted 15.10.2012).

In the initial «Mountland〉 workplan, this contribution was planned as a synthesis paper of Konstantin Gavazov's PhD work (1), which had a focus on an ecological experiment. The linkage of experimental data with the ecological modelling, however, gave rise to interdisciplinarity and the synthesis character. The timeline with respect to the Special Feature accelerated the work on this manuscript (6). This, however, asked for some flexibility with respect to the organization of Konstantin's work (4) since the original idea was to publish this manuscript after he had written his disciplinary contributions. Moreover, the linkage was only possible with the help of Alexander Peringer (modelling), François Gillet (adviser, internal reviewer), Thomas Spiegelberger (reviewer) and Alexandre Buttler (adviser, reviewer) who provided important input to the manuscript within a short time frame $(4,5)$. The parallel work on paper 3,4 and 5 helped to focus (and distinguish) the content of the manuscript (2). For this contribution, however, the parallel work on different (inter-)disciplinary manuscript had also a disadvantage. For the individual success of Konstantin's $\mathrm{PhD}$, it would have been much better if he wouldn't had been rushed to work on his synthesis before he actually published his individual/disciplinary work (2). One of the Figures in the original synthesis (Paper 10) that was based on Konstantin's data had to be removed because it would have precluded one of his individual papers.

Paper 3: A contextual analysis of land-use and vegetation changes in two wooded pastures in the Swiss Jura Mountains (accepted 26.9.2012)

This manuscript was planned as one chapter of the ECOS PhD candidate (Katy Lannas). Thus, it was originally planned before the synthesis was developed. Katy, however, stopped working on her $\mathrm{PhD}$ because of health reasons (1). Thus, Michael Kalbermatten stepped in for 6 months to work on the data analysis (4). The synthesis workshop in May 2011 showed that this work would fit very well in the Special Feature (6). This accelerated the development of the manuscript. The flexibility and availability of the lead author (Joel Chételat) and the dif- 
ferent co-authors (François Gillet, Alexander Peringer, Alexandre Buttler) allowed to focus the outline of the contribution and to effectively write the manuscript $(4,5)$. The results from this manuscript were an important input for paper 4, which was written later on. Thus, the coordination of results between the two contributions to the Special Feature emerged as difficulty and restrained an early completion of the manuscript (7). At the same time, however, the parallel writing of the other manuscripts helped to confine the content of the manuscript (2).

Paper 4: Past and future landscape dynamics in pasture-woodlands of the Swiss Jura Mountains under climate change (accepted 22.1.2013)

As in the case of paper 3, this work was originally planned to be part of Katy Lannas's PhD who quit for health reasons (1). At the synthesis workshop (October 2012), we realized that this contribution would be a helpful part of the Special Feature (6), because it outlined fundamental landscape ecological dynamics, which had not been published before and therefore would have been available as references in manuscripts 2 and 3 and 5. Without the flexibility to hire Alexander Peringer (available funds) (4) and his fast development / advancement of the model with the help of François Gillet and Alexandre Buttler (5), the contribution would not have been possible. Since the contribution was using input from paper 2, the coordination between the two manuscripts was challenging and delayed paper 2 (7). Still, the manuscript greatly profited from the collaboration within the whole ECOS group and their contributions (2).

Paper 5: Modelling social-ecological feedback effects in the implementation of payments for environmental services in pasture-woodlands (accepted 19.12.2012)

This contribution originated in the idea to combine the findings from the natural science and the social science part in the Jura, developed at the workshop in May 2011, and initiated by the coordinator being already familiar with the research in the Jura case study (6). It necessitated extending the land use model as well as collecting additional data, thus asking for a lot of flexibility. With the help of a master student and the availability of the «Mountland coordinator to write a first draft (4), the intensive collaboration between the disciplinary groups could be established (5). However, this flexibility came with costs. The work was planned ad hoc and the conceptual framework had been elaborated in parallel with the model implementation (7). In addition, the very interdisciplinary character of the manuscript and the short time frame made a coordination of the internal review difficult. Co-authors focused on their individual paragraphs within the manuscript rather than the contribution as a whole. (8). During the review process, the parallel writing of other manuscripts (and the revisions of the Jura papers in general) helped to improve the quality and the focus of the manuscript (2). Still, the coordination between the two model outputs was challenging due to limited time resources. There was always just a relatively small time window to exchange data (7). The lead and coordination of the subject editor was another important aspect (9). Without the concise and helpful comments of the subject editor who had a clear idea about the potential of earlier versions of the manuscript, a successful publication would not have been possible. The subject editor was able to give advice that helped to bridge the gaps that emerged from the ad hoc implementation of the conceptual framework elaborated in this context (two different time horizons in the models). The manuscript was revised four times before being accepted by the subject editor. 
Paper 6: Constructing Consistent Multi-Scale Scenarios by Transdisciplinary Processes: The Case of Mountain Regions Facing Global Change (accepted 15.10.2012)

This manuscript was planned as one chapter of the NSSI PhD candidate (Julia Brändle). Thus, the data collection and workshops for this transdisciplinary manuscript were available and based on the parallel work in «Mountland as planned in the initial proposal $(1,2,6)$. Since the outline of the manuscript was ready, the authors had enough time to coordinate an intensive internal review of the manuscript with other researchers and with stakeholders (8). In addition, this contribution was very well targeted to the chosen journal for the Special Feature (6).

Paper 7: Trade-offs between ecosystem services in a mountainous region (accepted 10.3.2013)

This manuscript was planned as one chapter of the AFEE PhD candidate (Simon Briner). The outline of the manuscript was defined before the workshop in May 2011 (1). The writing of the other chapter of Simon's PhD helped to focus the outline and content of the submitted manuscript (2). However, the first chapter of Simon's PhD (the description of the model) had some parallels to this contribution, and was published quite some time before the submission deadline (2). One of the reviewers doubted the added value of this manuscript. The subject editor (with a encompassing view on the Special Feature) managed to align the reviewer's claims and the authors' possibilities to adjust the manuscript (9). To accentuate the differences between the two chapters, the «Mountland» coordinator joined the author team after the second review. The additional author brought a) a new idea what the existing manuscript adds to the Special Feature (6), b) additional inputs from the parallel writing of the synthesis paper 10 (5); and c) the flexibility (time resources) to revise the manuscript (4).

Paper 8: Combining Policy Network and Model-Based Scenario Analysis: An Assessment of Future Ecosystem Goods and Services in Swiss Mountain Regions (accepted 19.12.2012)

As in the case of paper 5, the idea of this contribution emerged from the workshop in May 2011 with a clear focus on the Special Feature (6). In contrast to paper 5, however, there was a clear plan on how to integrate the two disciplinary approaches (6) and their results (7). The composition of the team allowed for an efficient, interactive writing process (5). However, the reviewers came from a specific research field and asked to focus the manuscript on one discipline only (10). The subject editor put a lot of effort to convince the reviewers to keep both approaches in an interdisciplinary way in the manuscript (9). In addition, the parallel writing (especially the contributions with a focus on modelling) helped to improve the quality of this contribution (2). In the end, time restrictions (and to a lesser extent also the limited length of the paper i.e. word count) did not allow for a full elaboration of the potential of the original idea (which was also criticized by one of the reviewers) (4).

Paper 9: Integrating expert knowledge into mapping ecosystem services tradeoffs for sustainable forest management (accepted 4.4.2013)

At the beginning, this contribution was not planned to be part of the Special Feature. Thus, it was based on earlier work parallel to the synthesis (1). At the synthesis workshop in October 2011, we decided to integrate this contribution into the Special Feature because a) it contained a valuation of Ecosystem Services (additional dimension of the «Mountland work) and b) it 
was based in the case study region Davos which otherwise would have been absent in the Special Feature (6). The reviewer was very skeptical about the submitted version of the manuscript, leading to a long list of comments. With a focus on the whole Special Feature, the subject editor asked the editor in chief whether the authors could re-submit a new version of the manuscript (9). Based on the extremely valuable inputs of the reviewer (10), the authors completely revised their contribution. This was only possible because a person at PLUS had time and the corresponding experience to write a new version of this manuscript $(4,5)$.

Paper 10: Sustainable land-use in mountain regions under global change: synthesis across scales and disciplines (accepted 24.1.2013)

The funding for a synthesis was cut by CCES in the initial proposal. Thus, there was no plan on how to realize the synthesis of the project. At a later stage, CCES decided to fund synthesis proposals. We developed the idea of different Special Features as synthesis output of 〈Mountland (6). Based on our vision CCES provided additional and crucial funding for the synthesis (flexibility with respect to money) (4). Moreover, the possibility to extend the appointment of the senior scientists (postdoctoral researchers) allowed maintaining the knowhow from the different research projects (5). In addition, we developed a methodological plan on how to summarize and synthesis our work based on the publication by Seppelt et al (2012) and organized a synthesis workshop. However, the coordination of results remained a major challenge since some of the PhD results were not available at that point in time (autumn 2011) (cf. paper 1). Thus, important results (e.g. avalanche land-use interaction from Davos) were not part of the synthesis (7). In addition, co-authors strongly focused on their contributed paragraphs rather than to revise the whole manuscript (8). This resulted in a long synthesis that was judged by the reviewer as a very long list but not actually as a synthesis. The very helpful comments of the reviewer helped to focus the synthesis considerably (10). The manuscript was shortened by $20 \%$. In this context, the parallel writing of synthesis articles for the Schweizerische Zeitschrift für Forstwesen and Agrarforschung helped to focus and improve the conclusions from our work (2). Again, the methodological background given by Seppelt et al (2012) and other reviews, i.e. a plan on how to proceed, formed an important basis for the writing of the final manuscript (6). At the end, however, time resources from the professors and senior scientists (i.e. most of the co-authors) were still limited to realize a throughout internal review of the manuscript (8). 